AperTO - Archivio Istituzionale Open Access dell'Università di Torino

\title{
Assessing the value relevance of accounting data after IFRS introduction in Europe
}

\section{This is the author's manuscript}

Original Citation:

Availability:

This version is available http://hdl.handle.net/2318/99480

since $2017-07-24 T 17: 38: 22 Z$

Terms of use:

Open Access

Anyone can freely access the full text of works made available as "Open Access". Works made available under a Creative Commons license can be used according to the terms and conditions of said license. Use of all other works requires consent of the right holder (author or publisher) if not exempted from copyright protection by the applicable law. 


\title{
Assessing the Value Relevance of Accounting Data After the Introduction of IFRS in Europe
}

\author{
Alain Devalle \\ Faculty of Economics and Business, University of Turin, C.so Unione Sovietica 218 bis - 10134 \\ Turin, Italy \\ e-mail: devalle@econ.unito.it
}

\section{Enrico Onali}

Bangor Business School, Hen Goleg, College Road, Bangor LL57 2DG, UK

e-mail: e.onali@bangor.ac.uk

\section{Riccardo Magarini}

Faculty of Economics and Business, University of Turin, C.so Unione Sovietica 218 bis - 10134 Turin, Italy

e-mail: magarini@econ.unito.it

\begin{abstract}
Since 2005, European-listed companies have been required to prepare their consolidated financial statements in accordance with the International Financial Reporting Standards (IFRS). We examine whether value relevance increased following the introduction of IFRS, using a sample of 3,721 companies listed on five European stock exchanges: Frankfurt, Madrid, Paris, London, and Milan. We find mixed evidence of an increase in value relevance. However, the influence of earnings on share price increased following the introduction of IFRS in Germany, France, and the United Kingdom, while the influence of book value of equity decreased (except for the United Kingdom).
\end{abstract}

\section{Introduction}

The recent financial crisis has shown that a lack of transparency in financial markets may result in a widespread fall in investor confidence. Eventually this phenomenon may lead to liquidity shortages and stock market crashes (OECD Observer, 2009). Opaque stock markets exacerbate the problem of informational asymmetry between insiders (primary

\footnotetext{
An earlier version of this paper was presented at the International Association of Accounting Education and Research conference, held in Munich in February 2009. The authors are indebted to two anonymous referees for helpful and constructive comments on an earlier draft of this paper. We are very grateful to John Goddard (Bangor University) for reading the paper several times and for giving us valuable feedback. We also wish to thank Frederick Choi (the editor), Klaus Schaeck, Aziz Jaafar, Lynn Hodgkinson, Jo Wells, Doris Merkl-Davies and seminar participants at Bangor University in October 2008.
} 
shareholders and directors) and outsiders (common shareholders and creditors).

Transparency in the financial markets is a crucial issue for society as a whole. In recent decades, an increasingly large number of individuals have poured money into domestic and foreign stock markets, through pension and mutual funds (Pilbeam, 2005). Transparent company accounts are beneficial to individual investors as well as institutional investors, and their comparability at national and international level is important. For this reason, the definition and enforcement of internationally recognised financial reporting standards is considered of paramount importance by standard setters. A lively debate is underway among academics as to whether it is possible to achieve international harmonisation of financial reporting standards. Harmonisation should facilitate cross-border investment, leading to increased market liquidity, and a reduction in the cost of capital.

In an effort to achieve transparency and harmonisation of financial reporting standards and to reinforce the integration of European capital markets, the European Union (EU) requires listed companies to prepare their consolidated financial statement in compliance with the International Financial Reporting Standards (IFRS) for fiscal years starting from 1 January 2005 (1606/2002 European Commission Regulation).

If the premise that IFRS have led to greater transparency and crossborder comparability of company accounts is correct, we should expect: first, that informational asymmetries have decreased because the adoption of IFRS, and that there is a closer relationship between accounting measures and market data; and second, that this relationship should be similar in all European countries.

This paper investigates whether the relationship between accounting measures and market data, or value relevance, has strengthened as a consequence of the adoption of IFRS. We examine companies listed on five European stock exchanges (Frankfurt, Madrid, Paris, Milan, and London). An investigation of the effects of IFRS on accounting systems throughout the world is important for two reasons: first, to understand whether the harmonisation process, strongly encouraged by standard setters throughout the world, is effective in improving cross-border comparability of accounting information; and second, to provide useful information regarding the potential consequences of either voluntary adoption of IFRS in the United States, or possible compulsory adoption in 2014 suggested by Securities and Exchange Commission (2008). ${ }^{1}$ Most of the extant literature examines the effects of IFRS either for a single 
country or for many countries but neglecting the impact of countryspecific cultural and legal traditions on the effectiveness of the new regulatory framework. In this study, we examine the effects of IFRS on five countries that are believed to differ in terms of legal system and size of capital markets. While the United Kingdom has a shareholderoriented accounting framework, accounting regulations in several continental European countries place less emphasis on the protection of outsiders from expropriation by insiders (La Porta et al., 1997).

Using panel-data regression analysis and a Chow test for structural breaks, we find that the reaction to IFRS in terms of value relevance differs according to the stock exchange considered. To our knowledge, this is the first paper that uses panel-data models to test for value relevance. The use of a Chow test is also an innovation: studies that compare value relevance for different countries or time periods rely on the comparison of the explanatory power of the models, without testing for a structural break in the coefficients. The absence of a structural break following the implementation of IFRS suggests that changes in value relevance might be due to other factors. To increase the robustness of the results, we use two models that are commonly employed for testing value relevance, as well as models that test for earnings smoothing and timely loss recognition. Value relevance, earnings smoothing, and timely loss recognition are all parts of the general concept of accounting quality (Barth et al., 2008).

Our main findings are that there has been an improvement in value relevance across the entire sample. These findings are consistent with Barth et al. (2008). Structural breaks in the coefficients of a price regression model (PRM) occur for all five countries. If the explanatory power of the regression is considered as a proxy for value relevance, then value relevance has decreased in Germany, Spain, and Italy. Among the countries considered, value relevance has increased due to the adoption of IFRS in the case of France and the United Kingdom. When changes in the magnitude of the coefficients for the book value of equity and earnings per share are examined, there is evidence of increased (decreased) value relevance for earnings in Germany and France (Italy). The value relevance of the book value of equity decreased (increased) in Germany, Spain, France, and Italy (the United Kingdom). When returns, rather than prices, are used as the dependent variable, structural breaks associated with the implementation of IFRS are found for Spain, Italy, and the United Kingdom. Among the countries considered, value relevance has increased due to the adoption of IFRS in the case of Spain, Italy, and the United 
Kingdom. The results for other measures of accounting quality, earnings variability, and timely loss recognition do not suggest that accounting quality improved after the implementation of IFRS.

The remainder of this paper is organised as follows. Section 2 reviews the literature. Section 3 describes the methodology and data. Section 4 reports the results. Section 5 reports robustness tests based on measures of accounting quality other than value relevance. Section 6 concludes.

\section{Literature Review}

\subsection{Comparison of International Accounting Standards (IAS)}

Differences between local accounting standards have been studied widely. A branch of this literature classifies accounting systems by characteristics of their legal system. It is common to identify an AngloSaxon (or Anglo-American) cluster and a Continental European cluster (Joos and Lang, 1994; Nobes, 1998; Ali and Hwang, 2000; Delvaille et al., 2005). D'Arcy (2001) argues that this taxonomy might be too simple to capture the heterogeneity among national accounting systems throughout the world.

A more sophisticated classification is developed by La Porta et al. (1997), who posit a link between the legal system, and the quality of protection for outsiders (both common shareholders and creditors). Differences in levels of protection for outsiders are ascribed to the legal system: a common law system is associated with stronger protection for outsiders, whereas a civil law system (also code law system) is associated with weaker protection. In turn, the quality of protection impinges on the characteristics of capital markets. Countries with better protection of outsider financiers against expropriation by insiders have larger capital markets and superior enforcement. Four groups are identified on the basis of this criterion: English, French, German, and Scandinavian. The French-origin group has the poorest protection for outsiders and the least developed capital markets. The English-origin group has the strongest protection and the most advanced capital markets. The German-origin and Scandinavian-origin clusters are located between these two extremes.

In many studies, the terms Anglo-Saxon and English-origin are synonymous. The German-origin and French-origin groups, including Spain and Italy, both form part of the Continental European cluster (Nobes and Parker, 2008). However, significant differences exist within the 
Continental European cluster (La Porta et al., 1997; Nobes, 1998, 2006). In particular, the French and Italian accounting systems are influenced by tax law, while the German system is influenced by commercial law. Delvaille et al. (2005) attributes differences between countries to differences between the levels of internationalisation of companies listed on the domestic stock exchange. More multinational enterprises are based in France and Germany than are based in Italy and Spain.

Financial statements prepared under the Continental European model are likely to report more conservative profits than those prepared under the Anglo-Saxon model (Demaria and Dufour, 2007). The main valuation principle is historical cost. Prudence dictates that only gains that are certain should be recorded, while appropriate provisions should be set aside for potential losses. The balance sheet value (historical cost) of an asset can decrease if its value is believed to have fallen, but it cannot increase except as a result of an exceptional event, or if an increase is justified by a specific law. In the Anglo-Saxon model, historical cost is frequently modified on the basis of revaluations to reflect "fair value," defined as "[...] the amount for which an asset could be exchanged, or a liability settled, between knowledgeable, willing parties in an arm's length transaction" (IAS 39).

IFRS have been heavily influenced by the shareholder-based orientation typical of the Anglo-Saxon system (Flower and Ebbers, 2002; Hung and Subramanyam, 2007), in which the principle of "fair value" is important but not always decisive (Cairns, 2006). The use of fair value impinges primarily on the book value of equity, which may be volatile (Devalle, 2008). IFRS have been introduced to increase the cross-border comparability of financial statements, which should lead to greater crossborder investment and improved allocative efficiency (Beneish et al., 2009). There is evidence of improved market liquidity for countries that have adopted IFRS, but there is no evidence of any consistent effect on Tobin's $q$ (the ratio of market to book value of equity) or the cost of capital (Daske et al., 2008). Some studies have investigated the effects of the adoption of IAS/IFRS on value relevance (see Section 2.2).

Table 1 summarises the main differences between the accounting systems of the five countries included in the present study: Germany, Spain, France, Italy, and the United Kingdom. Table 1a summarises general features of each accounting system, and presents comparisons with IFRS across the following categories: type of legal system, primary users of financial reports, accounting principles and valuation criteria, and the documents comprising a set of financial statements. Table $1 \mathrm{~b}$ compares 


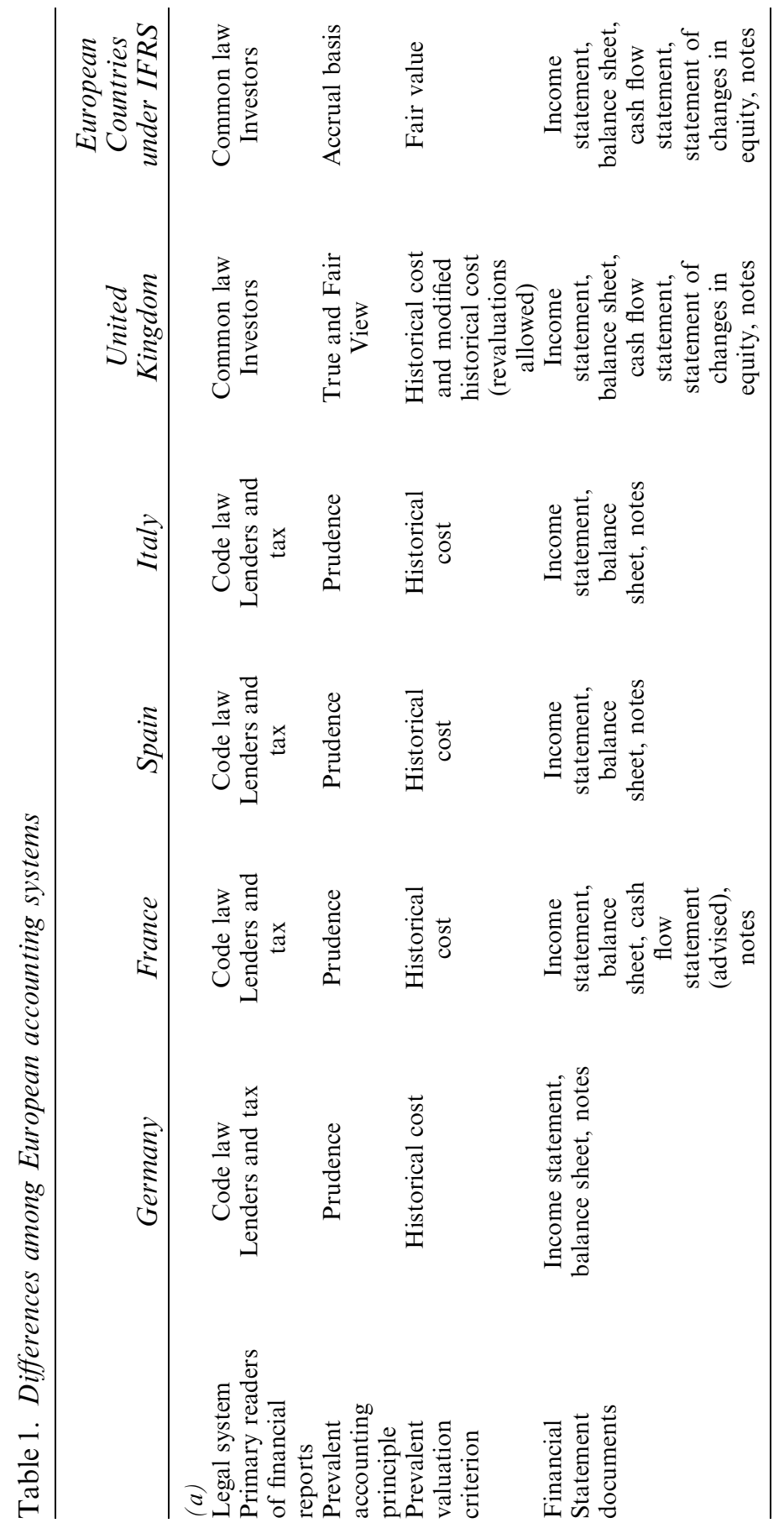




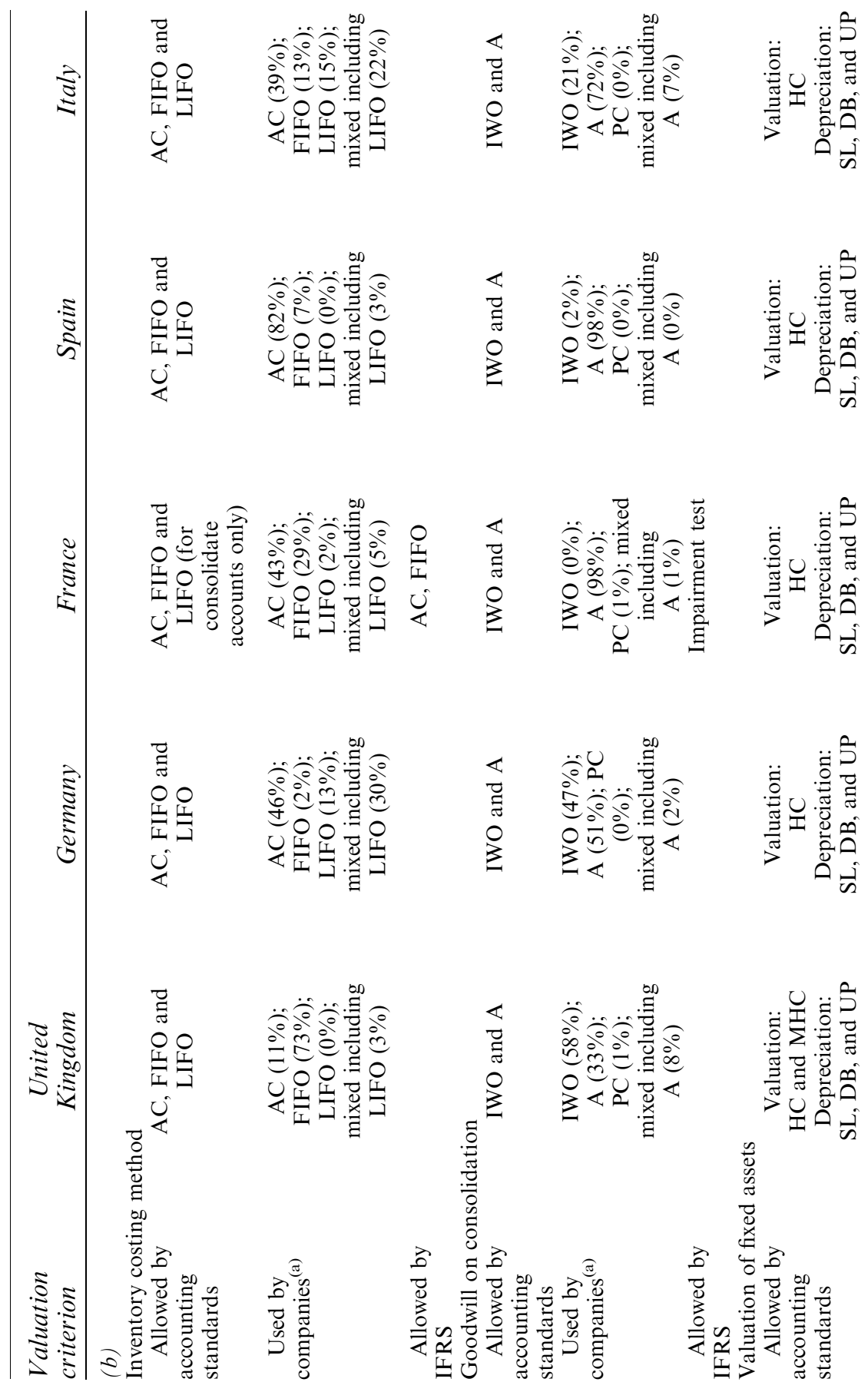







the asset valuation criteria permitted by Local generally accepted accounting criteria (GAAP) and IFRS, and reports Jaafar and McLeay's (2007) estimates of the percentages of companies that adopted each criterion in the years 1991, 1995, and 1999. The categories of assets considered are inventories, goodwill on consolidation, and fixed assets.

\subsection{IFRS and Value Relevance}

The introduction of IFRS represents a profound change for many European accounting models, and is expected to have an impact on the relationship between accounting data and stock prices. European managers and investors, especially those accustomed to the Continental European accounting system, need to assess the implications of IFRS adoption for accounting quality and value relevance (Hung and Subramanyam, 2007). Value relevance can be described as "[. . .] the ability of financial statement information to capture or summarise information that affects share values" (Hellström, 2006, p. 325). Research in this area is motivated by a view that historical cost accounting is an unreliable indicator of the true value of a firm. Collins et al. (1997) suggest the shift from an industry-oriented to a service-oriented economy lies at the root of this problem. Recently, doubts over the validity of value relevance studies (Holthausen and Watts, 2001) have been rebutted by Hellström (2006).

Table 2 provides an overview of the empirical literature on value relevance. ${ }^{2}$ Several early empirical studies report an increase in value relevance over time (Collins et al., 1997; Ely and Waymire, 1999; Francis and Schipper, 1999; Lev and Zarowin, 1999). However, scale effects might account for a spurious increase in the metrics used for value relevance (Brown et al., 1999), see Section 3. A spurious negative relationship between price and negative earnings (Collins et al., 1999; Papadaki and Siougle, 2007) has been ascribed to the transitory nature of losses, which impairs their information content (Hayn, 1995).

Several studies compare value relevance in developed and emerging economies. The value relevance of the German GAAP has been compared with that of the U.S. GAAP and IFRS (Harris et al., 1994; Bartov et al., 2005; Schiebel, 2006; Hung and Subramanyam, 2007), with mixed results. There are also mixed views as to whether the U.S. GAAP are more value relevant than IFRS (Harris and Muller, 1999; Van der Meulen et al., 2007). In a multi-country study, Ali and Hwang (2000) find value relevance is lower in the Continental European cluster than it is in the Anglo-Saxon cluster. IFRS are found not to be more value 
Table 2. Literature review on the use of value relevance models

\begin{tabular}{|c|c|c|c|}
\hline Paper & Sample period & Topic & Results \\
\hline $\begin{array}{l}\text { Harris et al. } \\
\text { (1994) }\end{array}$ & 1982-1991 & $\begin{array}{l}\text { Comparison of value } \\
\text { relevance German } \\
\text { GAAP and U.S. } \\
\text { GAAP }\end{array}$ & $\begin{array}{l}\text { Significant association } \\
\text { between accounting data } \\
\text { provided under German } \\
\text { GAAP and stock prices } \\
\text { and returns. Explanatory } \\
\text { power of earnings for } \\
\text { returns in Germany } \\
\text { comparable to that in the } \\
\text { United States. } \\
\text { Explanatory power of } \\
\text { book value of equity for } \\
\text { price significantly lower in } \\
\text { Germany than in the } \\
\text { United States. Little } \\
\text { evidence of improved } \\
\text { value relevance after } \\
\text { Accounting Directives } \\
\text { Law (1985) }\end{array}$ \\
\hline $\begin{array}{l}\text { Joos and Lang } \\
\text { (1994) }\end{array}$ & 1982-1990 & $\begin{array}{l}\text { Investigation of effects } \\
\text { of the European Union } \\
\text { (EU) directives on } \\
\text { value relevance in the } \\
\text { United Kingdom, } \\
\text { Germany, and France }\end{array}$ & $\begin{array}{l}\text { Improved value relevance } \\
\text { in all countries after the } \\
\text { EU directives }\end{array}$ \\
\hline $\begin{array}{l}\text { Harris and } \\
\text { Muller (1999) }\end{array}$ & 1992-1996 & $\begin{array}{l}\text { Comparison of value } \\
\text { relevance U.S. GAAP } \\
\text { and IAS }\end{array}$ & $\begin{array}{l}\text { Better value relevance for } \\
\text { IAS when stock price is } \\
\text { considered. Better value } \\
\text { relevance for U.S. GAAP } \\
\text { when stock return is } \\
\text { considered }\end{array}$ \\
\hline $\begin{array}{l}\text { Ali and } \\
\text { Hwang (2000) }\end{array}$ & 1986-1995 & $\begin{array}{l}\text { Comparison of value } \\
\text { relevance Continental } \\
\text { model and Anglo- } \\
\text { Saxon model }\end{array}$ & $\begin{array}{l}\text { Lower value relevance for } \\
\text { Continental model }\end{array}$ \\
\hline $\begin{array}{l}\text { Niskanen et al. } \\
(2000)\end{array}$ & 1984-1992 & $\begin{array}{l}\text { Evaluation of } \\
\text { incremental value } \\
\text { relevance of } \\
\text { reconciliation from } \\
\text { Finnish Local } \\
\text { Accounting Standards } \\
\text { (LAS) to IAS }\end{array}$ & $\begin{array}{l}\text { No evidence of value } \\
\text { relevance for } \\
\text { reconciliation of Finnish } \\
\text { LAS to IAS at an } \\
\text { aggregate level. Significant } \\
\text { value relevance for } \\
\text { reconciling adjustments of } \\
\text { untaxed reserves and } \\
\text { consolidation differences }\end{array}$ \\
\hline $\begin{array}{l}\text { Babalyan } \\
(2001)\end{array}$ & 1997-1999 & $\begin{array}{l}\text { Comparison of value } \\
\text { relevance according } \\
\text { Swiss GAAP, U.S. } \\
\text { GAAP and IAS }\end{array}$ & $\begin{array}{l}\text { U.S. GAAP are more } \\
\text { value relevant than IAS } \\
\text { and Swiss GAAP. Firm } \\
\text { size effect discovered and } \\
\text { ascribed to greater } \\
\text { demand for information } \\
\text { for larger firms }\end{array}$ \\
\hline
\end{tabular}


Table 2. (Continued.)

\begin{tabular}{|c|c|c|c|}
\hline Paper & Sample period & Topic & Results \\
\hline $\begin{array}{l}\text { Gornik- } \\
\text { Tomaszewski } \\
\text { and } \\
\text { Jermakowicz } \\
(2001)\end{array}$ & 1996-1998 & $\begin{array}{l}\text { Investigation of effects } \\
\text { of EU directives on } \\
\text { value relevance of } \\
\text { accounting data } \\
\text { reported by listed } \\
\text { Polish companies. }\end{array}$ & $\begin{array}{l}\text { Current earnings and } \\
\text { lagged book value are } \\
\text { significantly associated to } \\
\text { stock prices and the } \\
\text { incremental information } \\
\text { content of lagged book } \\
\text { value is greater than that } \\
\text { of current earnings }\end{array}$ \\
\hline $\begin{array}{l}\text { Bartov et al. } \\
(2005)\end{array}$ & 1998-2000 & $\begin{array}{l}\text { Comparison of value } \\
\text { relevance German } \\
\text { GAAP, U.S. GAAP } \\
\text { and IAS }\end{array}$ & $\begin{array}{l}\text { U.S. GAAP are more } \\
\text { value relevant than IAS, } \\
\text { which are in turn more } \\
\text { value relevant than } \\
\text { German GAAP }\end{array}$ \\
\hline $\begin{array}{l}\text { Lin and Chen } \\
(2005)\end{array}$ & 1995-2000 & $\begin{array}{l}\text { Evaluation of } \\
\text { incremental value } \\
\text { relevance of } \\
\text { reconciliation from } \\
\text { Chinese Accounting } \\
\text { Standards (CAS) to } \\
\text { IAS }\end{array}$ & $\begin{array}{l}\text { Evidence of little value } \\
\text { relevance for } \\
\text { reconciliation of CAS to } \\
\text { IAS, mainly for stock } \\
\text { prices of B-type shares }\end{array}$ \\
\hline $\begin{array}{l}\text { Schiebel } \\
(2006)\end{array}$ & 2000-2004 & $\begin{array}{l}\text { Comparison of value } \\
\text { relevance German } \\
\text { GAAP and IFRS }\end{array}$ & $\begin{array}{l}\text { German GAAP are more } \\
\text { value relevant than IFRS }\end{array}$ \\
\hline $\begin{array}{l}\text { Hellström } \\
\text { (2006) }\end{array}$ & 1994-2001 & $\begin{array}{l}\text { Investigation of } \\
\text { changes in value } \\
\text { relevance in Czech } \\
\text { Republic (transitional } \\
\text { economy) }\end{array}$ & $\begin{array}{l}\text { Improved value relevance } \\
\text { over time }\end{array}$ \\
\hline $\begin{array}{l}\text { Callao et al. } \\
(2007)\end{array}$ & 2004-2005 & $\begin{array}{l}\text { Investigation of effects } \\
\text { of IFRS adoption on } \\
\text { value relevance in } \\
\text { Spain }\end{array}$ & $\begin{array}{l}\text { Worse value relevance } \\
\text { when IFRS are applied }\end{array}$ \\
\hline $\begin{array}{l}\text { Dobija and } \\
\text { Klimczak } \\
(2007)\end{array}$ & 1997-2006 & $\begin{array}{l}\text { Investigation of } \\
\text { changes in value } \\
\text { relevance in Poland } \\
\text { (transitional economy) }\end{array}$ & $\begin{array}{l}\text { Better value relevance of } \\
\text { accounting earnings }\end{array}$ \\
\hline $\begin{array}{l}\text { Hung and } \\
\text { Subramanyam } \\
(2007)\end{array}$ & 1998-2002 & $\begin{array}{l}\text { Investigation of effects } \\
\text { of IAS adoption on } \\
\text { value relevance in } \\
\text { Germany }\end{array}$ & $\begin{array}{l}\text { No evidence of better } \\
\text { value relevance of IAS } \\
\text { over German GAAP }\end{array}$ \\
\hline $\begin{array}{l}\text { Naceur and } \\
\text { Nachi (2007) }\end{array}$ & 1992-2001 & $\begin{array}{l}\text { Investigation of effects } \\
\text { of changes in Tunisian } \\
\text { GAAP (in particular, } \\
1997 \text { accounting } \\
\text { reform) on value } \\
\text { relevance }\end{array}$ & $\begin{array}{l}\text { Better value relevance } \\
\text { after the } 1997 \text { accounting } \\
\text { reform. No evidence of } \\
\text { firm size effect }\end{array}$ \\
\hline $\begin{array}{l}\text { Van der } \\
\text { Meulen et al. } \\
(2007)\end{array}$ & 2000-2002 & $\begin{array}{l}\text { Comparison of value } \\
\text { relevance U.S. GAAP } \\
\text { and IFRS earnings }\end{array}$ & $\begin{array}{l}\text { No evidence of different } \\
\text { value relevance between } \\
\text { U.S. GAAP and IFRS } \\
\text { earnings }\end{array}$ \\
\hline
\end{tabular}


Table 2. (Continued.)

\begin{tabular}{|c|c|c|c|}
\hline Paper & Sample period & Topic & Results \\
\hline $\begin{array}{l}\text { Jermakowicz } \\
\text { et al. (2007) }\end{array}$ & 1995-2004 & $\begin{array}{l}\text { Comparison of the } \\
\text { value relevance of } \\
\text { accounting income } \\
\text { reported under } \\
\text { German HGB, IFRS, } \\
\text { and U.S. GAAP }\end{array}$ & $\begin{array}{l}\text { Better value relevance } \\
\text { adopting IFRS or U.S. } \\
\text { GAAP }\end{array}$ \\
\hline $\begin{array}{l}\text { Gjerde et al. } \\
(2008)\end{array}$ & 1965-2004 & $\begin{array}{l}\text { Investigation of } \\
\text { changes in value } \\
\text { relevance in } \\
\text { Norwegian GAAP } \\
\text { over time (transition } \\
\text { from Continental to } \\
\text { Anglo-Saxon model) }\end{array}$ & $\begin{array}{l}\text { Better value relevance } \\
\text { over time }\end{array}$ \\
\hline $\begin{array}{l}\text { Horton and } \\
\text { Serafeim } \\
(2008)\end{array}$ & 2005 & $\begin{array}{l}\text { Evaluation of } \\
\text { incremental value } \\
\text { relevance of } \\
\text { reconciliation from } \\
\text { U.K. GAAP to IFRS }\end{array}$ & $\begin{array}{l}\text { Reconciliation of U.K. } \\
\text { GAAP to IFRS is value } \\
\text { relevant }\end{array}$ \\
\hline $\begin{array}{l}\text { Dedman et al. } \\
\text { (2009) }\end{array}$ & 1991-2006 & $\begin{array}{l}\text { Evaluation of value } \\
\text { relevance of R\&D } \\
\text { expenditure in the } \\
\text { United Kingdom }\end{array}$ & $\begin{array}{l}\mathrm{R} \& \mathrm{D} \text { expenditure is value } \\
\text { relevant }\end{array}$ \\
\hline
\end{tabular}

Notes:

${ }^{(a)}$ In the Chinese stock market, A-type shares are those available only to domestic investors, whereas B-type shares are available to both foreign and domestic investors (since 2001).

relevant than the national GAAP in Finland (Niskanen et al., 2000) and Switzerland (Babalyan, 2001). Among emerging economies, GornikTomaszewski and Jermakowicz (2001) find value relevance in Poland is similar to that in more developed economies, while Lin and Chen (2005) find the Chinese GAAP are more value relevant than IFRS.

The impact of regulation on value relevance has also been studied. Joos and Lang (1994) find value relevance improved in France, Germany, and the United Kingdom as a result of the EU fourth and seventh directives. Changes in national accounting regulation are found to have improved value relevance in the Czech Republic (Hellström, 2006), Tunisia (Naceur and Nachi, 2007), Poland (Dobija and Klimczak, 2007), and Norway (Gjerde et al., 2008). The impact of IFRS on value relevance has been investigated, with mixed results, for the United Kingdom (Horton and Serafeim, 2008), Spain (Callao et al., 2007), and Germany (Jermakowicz et al., 2007).

In this study, we aim to investigate whether value relevance has strengthened as a consequence of the adoption of IFRS in Germany, (C) 2010 Blackwell Publishing Ltd. 
Spain, France, Italy, and the United Kingdom. IFRS should lead to increased value relevance because they should enhance the cross-border comparability of financial statements and the allocative efficiency of stock markets (Beneish et al., 2009). An important feature of IFRS is that they limit managers' discretion in choosing accounting alternatives. Limiting managers' discretion, coupled with more rigorous enforcement, should lead to higher value relevance. However, a lack of flexibility in the range of available accounting alternatives may impair the ability of managers to report accounting measures that reflect the underlying economic conditions of a firm, and lax enforcement could undermine the effectiveness of IFRS (Barth et al., 2008). Therefore, it is hard to determine whether IFRS should lead to higher or lower value relevance.

\section{Methodology and Data}

In order to assess the value relevance of a set of accounting measures, a choice exists between two perspectives (Hellström, 2006). The "measurement perspective" examines the association between accounting and market data, while the "signalling perspective" examines changes in market value following announcements of accounting information. This study adopts the measurement perspective, in order to investigate whether the introduction of IFRS has enhanced value relevance in Europe.

Most "measurement perspective" studies rely on Ohlson's (1995) linear information model (LIM), in which firm value is a function of book value of equity and expected future residual (or abnormal) earnings. ${ }^{3}$ This relationship is based on the assumption of clean surplus accounting: changes in shareholders' net equity that do not emanate from transactions with shareholders (dividends, share repurchases, or offerings) should appear in the income statement. Therefore, current book value of equity is defined by the following identity: book value of equity from the previous year minus current dividends minus share repurchases (plus in the case of share offerings) plus earnings.

\subsection{The PRM}

Following Barth et al. (2008), our first metric for value relevance is the explanatory power of a regression of the share price of company $i(i=1, \ldots, N)$ in year $t(t=1, \ldots, T)$, denoted by $P_{i t}$, on book value of equity per share, denoted by $B_{i t}$, and earnings per share, denoted by $E_{i t}$. This model, commonly known as PRM derives from Ohlson's (1995) 
LIM. To allow for price changes that are due to mean differences across industries or to cross listing, $P_{i t}$ is pre-regressed on industry and cross listing-fixed effects. The residuals from this pre-regression, $P_{i t}^{*}$, are regressed on $B_{i t}$ and $E_{i t}{ }^{4}$

Because of multiple observations, $t$, for each company, $i$, individual effects might cause the values of $P_{i t}^{*}$ for the same $i$ to cluster together. Intra-group clustering can be tackled using panel-data models, which split the residual of the regression of $P_{i t}^{*}$ on $B_{i t}$ and $E_{i t}$ into two components: an individual (or fixed) component, which allows for unobservable non-time-varying characteristics of $i$, denoted by $\eta_{i}$, and a random time-varying component, denoted by $\varepsilon_{i t}$.

The random effects model (REM) assumes $\eta_{i}$ is distributed randomly across companies, and there is no correlation between the covariates $\left(B_{i t}\right.$ and $E_{i t}$ ) and $\eta_{i}$ (the orthogonality assumption). The REM uses generalised least squares (GLS) estimation to obtain efficient estimates of the coefficients on $B_{i t}$ and $E_{i t}$. If the orthogonality assumption is invalid, however, these coefficient estimates are inconsistent. In this case, the fixed effect model (FEM) should be used. The FEM does not require that $\eta_{i}$ is distributed randomly across units. The FEM disposes of the individual effects by subtracting from each observation the within-group averages of the dependent variable $\left(\bar{P}_{i}^{*}\right)$ and the covariates $\left(\bar{B}_{i}\right.$ and $\left.\bar{E}_{i}\right)$. Accordingly, the FEM is also known as the within-group estimator. Because $\eta_{i}$ is constant for each $i$, de-meaning eliminates the individual effects:

$$
P_{i t}^{*}-\bar{P}_{i}^{*}=\beta_{1}\left(B_{i t}-\bar{B}_{i}\right)+\beta_{2}\left(E_{i t}-\bar{E}_{i}\right)+u_{i t}-\bar{u}_{i}
$$

where $u_{i t}=\varepsilon_{i t}+\eta_{i}$ and $u_{i t}-\bar{u}_{i}=\varepsilon_{i t}-\bar{\varepsilon}_{i}=\varphi \sim N\left(0, \sigma^{2}\right)$.

In this study, the FEM is used to analyse the relationship between share prices and accounting data, because the FEM tackles the issue of intra-group correlation. Another important issue for the choice of estimation method concerns the possibility of scale effects that could impair the measurement of explanatory power (the coefficient of determination, $R^{2}$ ) before and after the implementation of IFRS. Scale effects refer to the influence of size on both accounting measures and share price: companies with higher (lower) share price are likely to have larger (smaller) book value of equity and larger (smaller) earnings per share (Easton and Sommers, 2003). Scale effects may produce spurious correlation between the dependent variable and the regressors of equation (1), and hinder the comparability of explanatory power between two 
or more sub-samples (Brown et al., 1999; Gu, 2001; K. Ota, unpublished paper). With the FEM, subtracting the within-group means from each observation eliminates scale effects. This technique is preferred to the alternative approach of deflation of all variables by a common factor, because there is a lack of consensus over the choice of deflator (Dedman et al., 2009). ${ }^{5}$ For example, Lang et al. (2006) use the lagged share price; ${ }^{6}$ in our opinion, however, this procedure does not eliminate scale effects, because the individual effect $\eta_{i}$ is not eliminated from the error term. ${ }^{7}$

Following Barth et al. (2005), we allow for the influence on share price of variables other than accounting information by including $v_{i t}=P_{i t-1}^{*}-$ $\hat{P}_{i t-1}^{*}$ as an additional independent variable, where $\hat{P}_{i t-1}^{*}$ is the fitted value of $P_{i t-1}^{*}$ according to (1):

$$
P_{i t}^{*}-\bar{P}_{i}^{*}=\beta_{1}\left(B_{i t}-\bar{B}_{i}\right)+\beta_{2}\left(E_{i t}-\bar{E}_{i}\right)+\beta_{3}\left(v_{i t}-\bar{v}_{i}\right)+u_{i t}-\bar{u}_{i} .
$$

A Chow test is used to establish whether the switch to IFRS caused a structural break in the relationship between share price and accounting data:

$$
C H O W=\frac{\left[R S S-\left(R S S_{1}+R S S_{2}\right)\right] /\left(2 k-k_{1}-k_{2}\right)}{\left(R S S_{1}+R S S_{2}\right) /\left(n_{1}+n_{2}-k_{1}-k_{2}\right)}
$$

where $R S S$ is the residual sum of squares of (2) for the entire sample period, $k$ is the number of coefficients, $R S S_{1}$ and $R S S_{2}$ are the residual sums of squares for the pre-IFRS period and the IFRS period, $n_{1}$ and $n_{2}$ are the numbers of observations for the two periods, and $k_{1}$ and $k_{2}$ are the numbers of coefficients. $\mathrm{CHOW}$ follows an $F$-distribution with degrees of freedom $\left(2 k-k_{1}-k_{2}\right)$ and $\left(n_{1}+n_{2}-k_{1}-k_{2}\right)$. The null hypothesis is that the coefficients on $E_{i t}$ and $B_{i t}$ do not vary between the two periods. If the null is rejected, a single set of coefficients in (2) does not adequately capture the relationship between the dependent and the independent variables for the entire sample period. There is a structural break, and the coefficients $\beta_{1}, \beta_{2}$, and $\beta_{3}$ differ significantly between the pre-IFRS and the IFRS periods.

\subsection{The Return Regression Model (RRM)}

A second variant of Ohlson's (1995) model has been used widely to test the robustness of results obtained using the PRM. First taking the differences of share price, book value of equity per share, and earnings per share yields

$$
P_{i t}-P_{i t-1}=B_{i t}-B_{i t-1}+E_{i t}-E_{i t-1} .
$$


Using the clean surplus relation

$$
B_{i t}=B_{i t-1}+E_{i t}-D_{i t}
$$

where $D_{i t}>=0$ denotes a dividend. By manipulating (5), the following relationships are obtained:

$$
\begin{gathered}
P_{i t}-P_{i t-1}=\left(B_{i t-1}+E_{i t}-D_{i t}\right)-B_{i t-1}+E_{i t}-E_{i t-1} \\
R_{i t}=E_{i t}+\Delta E_{i t}
\end{gathered}
$$

where $R_{i t}=P_{i t}-P_{i t-1}+D_{i t}$ and $\Delta E_{i t}=E_{i t}-E_{i t-1}$.

The PRM describes the relationship between share price and accounting data, while (7) describes the relationship between changes in the share price (adjusted for dividends) and accounting data. Commonly, both sides of (7) are deflated by $P_{i t-1}$ to adjust for scale effects. The resulting model is referred to as the RRM. By analogy with (2), however, we prefer the following within-group (FEM) panel-data specification ${ }^{8}$ :

$$
R_{i t}^{*}-\bar{R}_{i}^{*}=\beta_{1}\left(E_{i t}-\bar{E}_{i}\right)+\beta_{2}\left(\Delta E_{i t}-\Delta \bar{E}_{i}\right)+u_{i t}-\bar{u}_{i}
$$

where $R_{i t}^{*}$ are the residuals of a regression of $R_{i t}$ on industry and crosslisting fixed effects and $u_{i t}=\varepsilon_{i t}+\eta_{i}$. To mitigate problems caused by transitory earnings (Ota, unpublished paper), we use Earnings Before Interest, Taxes, Depreciation, and Amortisation (EBITDA) per share instead of earnings per share, and consider only those observations for which earnings per share are positive. ${ }^{9}$ A Chow test is employed to determine whether there was a structural break in the relationship between market data and accounting measures after the implementation of the IFRS. Observations for $t=2005$ are excluded, in order to eliminate cases where the calculation of $R_{i t}^{*}$ and $\Delta E_{i t}$ would be based on data from both the pre-IFRS period $(t-1=2004)$ and the IFRS period $(t=2005)$.

\subsection{Data}

The regression models described in Sections 3.1 and 3.2 are estimated using consolidated accounts and share price data collected from the database Thomson Analytics, for the period 2002-2007. The share prices are from the date 3 months after the closing year date (as in King and Langli, 1998; Kimberly, 2002; Hellström, 2006; Van der Meulen et al., 2007). 
Table 3. Construction of the sample

\begin{tabular}{lcc}
\hline & $\begin{array}{c}\text { Number of } \\
\text { observations } \\
\text { excluded }\end{array}$ & $\begin{array}{c}\text { Number of } \\
\text { obsertions } \\
\text { left }\end{array}$ \\
\hline Selection process: steps & & 32,076 \\
\hline $\begin{array}{l}\text { Worldscope 2002-2003-2004-2005-2006-2007 } \\
\text { Observations excluded because of accounting standards }\end{array}$ & $-14,716$ & 17,360 \\
$\begin{array}{l}\text { Observations excluded because of missing values for share } \\
\text { price, book value of equity and earnings }\end{array}$ & $-2,858$ & 14,502 \\
$\begin{array}{l}\text { Observations excluded because of a zero or negative book } \\
\text { value of equity }\end{array}$ & -598 & 13,904 \\
$\begin{array}{l}\text { Observations excluded because of a book value of equity } \\
\text { larger than the total assets }\end{array}$ & -36 & 13,868 \\
$\begin{array}{l}\text { Observations excluded because of missing data on the } \\
\text { total number of outstanding shares }\end{array}$ & -11 & 13,857 \\
$\begin{array}{l}\text { Observations excluded because of a price to earnings ratio } \\
\text { above (below) the } 0.99 \text { (0.01) percentile }\end{array}$ & -8 & 13,849 \\
\hline
\end{tabular}

Notes:

(a) These companies were either voluntary adopters of IFRS before IFRS became compulsory or they published their financial statements according to a standards different from their Local GAAP.

Table 3 summarizes the sample selection process, showing for each step the number of observations eliminated from the sample and the remaining observations. Only companies reporting under Local GAAP before the mandatory switch to IFRS in 2005 are included in the sample. ${ }^{10}$ Companies reporting under U.S. GAAP or other accounting principles are excluded. Observations for which the book value of equity is zero or negative are excluded, because of possible interference with local regulations concerning financial distress. Other exclusion criteria are as follows: book value of equity exceeds assets, number of shares outstanding missing, and price-earnings ratio either smaller than the 0.01 percentile or greater than the 0.99 percentile. The latter criterion is applied to reduce the impact of price volatility on the results. The 0.01 and 0.99 percentiles are calculated on a per-country basis. The sample selection criteria yield 13,849 usable observations on 3,721 companies.

\section{Results}

\subsection{Preliminary Analysis}

Table 4 reports descriptive statistics by country for: share price, $P$; book value of equity per share, $B V P S$; earnings per share, $E P S$; cum-dividend 


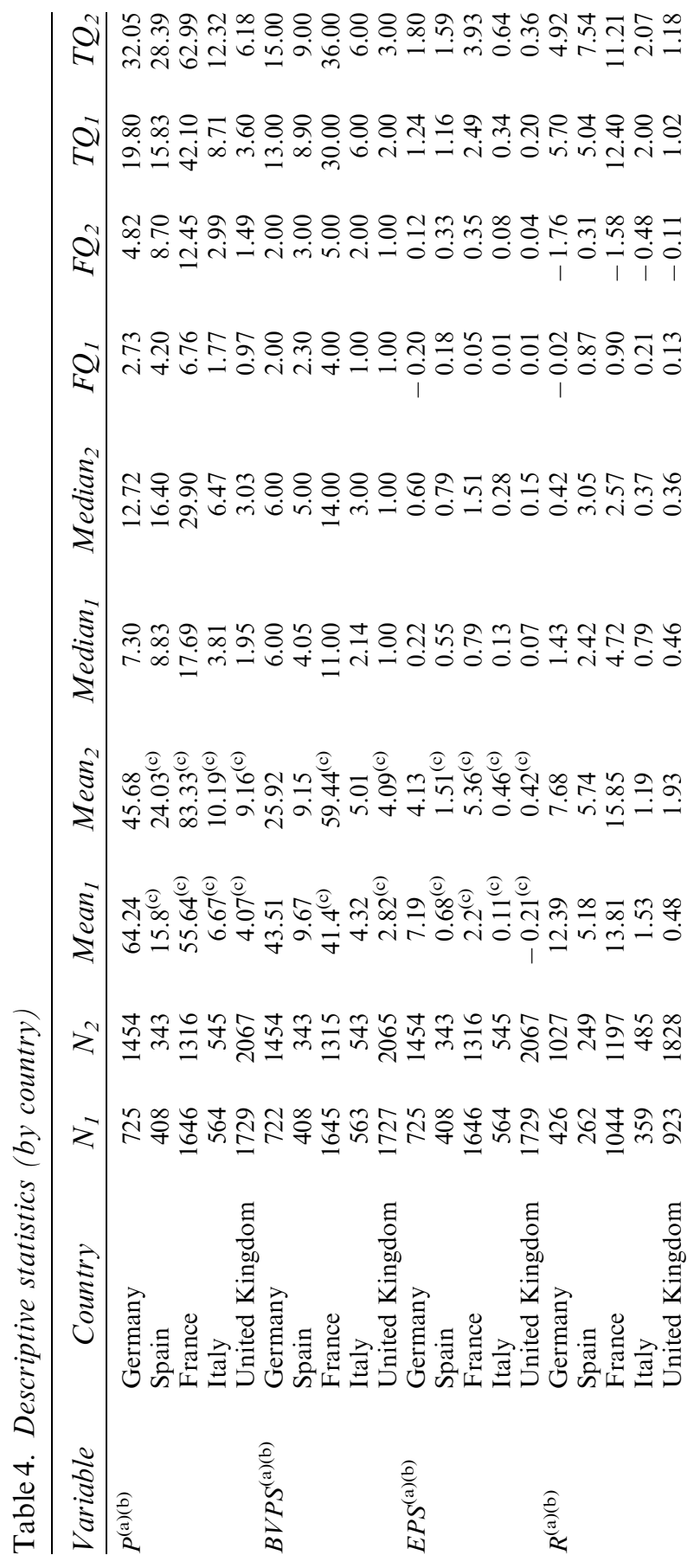




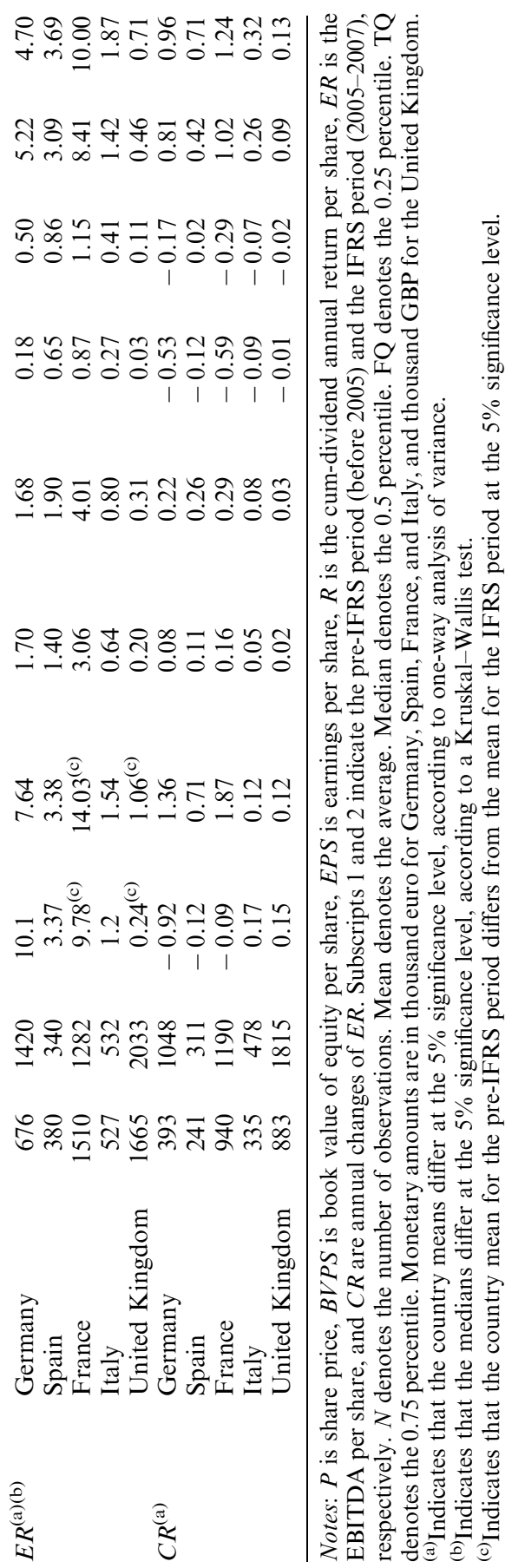


return, $R$; EBITDA per share, $E R$; and the change in EBITDA per share, $C R$. Statistically significant differences between the sample means of each variable for the pre-IFRS and IFRS periods are identified using $t$-tests with unequal variances. The average $P$ for the pre-IFRS period is significantly smaller for the IFRS period for all countries except Germany. The average BVPS is significantly larger for the IFRS period for France and the United Kingdom. The average EPS is significantly larger for the IFRS period for all countries except Germany. For the United Kingdom, the average EPS for the pre-IFRS period is negative. The average $R$ and $C R$ do not differ significantly between the pre-IFRS and IFRS periods. The average $E R$ is significantly larger for the IFRS period for France and the United Kingdom. These preliminary results suggest that in the IFRS period, there were significant changes in the average values of some variables used in the PRM and RRM. However, these results say nothing about changes in the explanatory power of the PRM and RRM. Neither do they provide any information as to whether the relationship between $P$ or $R$ (market performance measures) and $B V P S, E P S, E R$, and $C R$ (accounting performance measures) changed as a result of IFRS adoption.

Statistically significant differences between the sample means of each variable for different countries, for either the pre-IFRS period or the IFRS period, are identified using one-way analysis of variance tests. Statistically significant differences for the sample medians are identified using Kruskal-Wallis tests. With the exception of $C R$, the sample means of all variables differ between countries for both the pre-IFRS period and the IFRS period. The sample medians of all variables differ between countries for the pre-IFRS and the IFRS period. These preliminary results suggest that the analysis should be carried out on a per-country basis, rather than for the entire sample, as in some of the extant literature (for instance, Barth et al., 2008).

\subsection{Results for the PRM}

Table 5 reports the estimation results for equation (2) (within-group estimation of the PRM), from a pooled estimation for all five countries, and from individual estimations for each country separately.

In the pooled estimation, the Chow test is significant at the 1 per cent level. This suggests a structural break in the relationship between market data and the accounting measures occurred as a result of the switch to IFRS. The restricted model based on (2), in which the same coefficients 
Table 5. Price regression model: within-group estimation results

\begin{tabular}{|c|c|c|c|c|c|c|c|c|c|}
\hline \multirow[b]{2}{*}{ Variables } & \multicolumn{3}{|c|}{ All countries } & \multicolumn{3}{|c|}{ Germany } & \multicolumn{3}{|c|}{ Spain } \\
\hline & Pooled & $G A A P$ & IFRS & Pooled & $G A A P$ & IFRS & Pooled & $G A A P$ & IFRS \\
\hline$B_{i t}$ & $\begin{array}{l}0.9011^{\text {**** }} \\
(0.0088)\end{array}$ & $\begin{array}{l}2.4235^{* * * *} \\
(0.1146)\end{array}$ & $\begin{array}{l}0.2798 \text { **** } \\
(0.0236)\end{array}$ & $\begin{array}{c}* 2724 * * \\
(0.0314)\end{array}$ & $\begin{array}{l}3.1261^{* * * * *} \\
(0.1231)\end{array}$ & $\begin{array}{l}0.2416^{* * * *} \\
(0.0592)\end{array}$ & $\begin{array}{l}2.3103^{\text {***** }} \\
(0.1276)\end{array}$ & $\begin{array}{l}2.6377^{\text {*冰*** }} \\
(0.6877)\end{array}$ & $\begin{array}{c}0.6526^{*} \\
(0.3411)\end{array}$ \\
\hline$E_{i t}$ & $\begin{array}{c}-0.2050^{\text {*** }} \\
(0.0191)\end{array}$ & $\begin{array}{c}0.2455^{* * * *} \\
(0.0213)\end{array}$ & $\begin{array}{l}2.4420^{* * * *} \\
(0.0944)\end{array}$ & $\begin{array}{c}0.3350^{* * *} \\
(0.0607)\end{array}$ & $\begin{array}{c}0.3408^{* * * * * * *} \\
(0.0189)\end{array}$ & $\begin{array}{c}0.4521 * * \\
(0.1947)\end{array}$ & $\begin{array}{c}-1.4322^{* * * *} \\
(0.3223)\end{array}$ & $\begin{array}{c}* 1.4198^{* * *} \\
(0.6159)\end{array}$ & $\begin{array}{c}0.9194 * \\
(0.4746)\end{array}$ \\
\hline$v_{i t}$ & $\begin{array}{l}0.5349^{* * *} \\
(0.0134)\end{array}$ & $\begin{array}{l}0.1693^{* * * *} \\
(0.0486)\end{array}$ & $\begin{array}{c}-0.1520^{* * * *} \\
(0.0192)\end{array}$ & $\begin{array}{r}* 0.1852^{* * *} \\
(0.0647)\end{array}$ & $\begin{array}{c}0.0563 \\
(0.0512)\end{array}$ & $\begin{array}{c}-0.0911^{* *} \\
(0.037)\end{array}$ & $\begin{array}{l}0.4349^{* * * * *} \\
(0.0532)\end{array}$ & $\begin{array}{l}0.3524^{* * *} \\
(0.1354)\end{array}$ & $\begin{array}{r}-0.0567 \\
(0.0709)\end{array}$ \\
\hline$N$ & 8049 & 3015 & 5034 & 1512 & 426 & 1086 & 588 & 263 & 325 \\
\hline \multirow[t]{2}{*}{ CHOW } & \multicolumn{2}{|c|}{$7.1824 * * *$} & 0.577 & \multicolumn{2}{|c|}{$30.7650^{* * * *}$} & 0.51546 & \multicolumn{2}{|l|}{$4.0507^{* * * *}$} & 0.0733 \\
\hline & & France & & & Italy & & & nited Kingdon & \\
\hline Variables & Pooled & $G A A P$ & IFRS & Pooled & $G A A P$ & IFRS & Pooled & $G A A P$ & IFRS \\
\hline$B_{i t}$ & $\begin{array}{l}0.5596^{* * * *} \\
(0.0184)\end{array}$ & $\begin{array}{l}1.3255^{* * * *} \\
(0.2473)\end{array}$ & $\begin{array}{l}0.5938^{* * * *} \\
(0.0321)\end{array}$ & $\begin{array}{l}1.0170^{* * * *} \\
(0.0886)\end{array}$ & $\begin{array}{l}1.5680^{* * * *} \\
(0.2906)\end{array}$ & $\begin{array}{l}0.6789^{* * * *} \\
(0.2585)\end{array}$ & $\begin{array}{l}1.9557^{* * * *} \\
(0.1572)\end{array}$ & $\begin{array}{l}0.6148^{* * * *} \\
(0.1560)\end{array}$ & $\begin{array}{l}1.5977^{* * * *} \\
(0.2532)\end{array}$ \\
\hline$E_{i t}$ & $\begin{array}{l}1.9260^{* * * *} \\
(0.1059)\end{array}$ & $\begin{array}{c}0.3776 \\
(0.2980)\end{array}$ & $\begin{array}{l}2.2489^{* * * *} \\
(0.1141)\end{array}$ & $\begin{array}{l}1.3552^{* * * *} \\
(0.2630)\end{array}$ & $\begin{array}{l}1.3596^{* * * * *} \\
(0.3930)\end{array}$ & $\begin{array}{c}0.8483^{*} \\
(0.4407)\end{array}$ & $\begin{array}{l}9.1317^{* * * *} \\
(0.3254)\end{array}$ & $\begin{array}{c}-1.7607^{* * * *} \\
(0.1460)\end{array}$ & $\begin{array}{l}12.9734 * * * \\
(0.5465)\end{array}$ \\
\hline$v_{i t}$ & $\begin{array}{l}0.6759^{* * * * *} \\
(0.0195)\end{array}$ & $\begin{array}{c}-0.5310^{* * * *} \\
(0.0805)\end{array}$ & $\begin{array}{l}* 0.0379 \\
(0.0259)\end{array}$ & $\begin{array}{l}0.1096^{* *}- \\
(0.0456)\end{array}$ & $\begin{array}{l}-0.1851^{\text {**** }} \\
(0.0671)\end{array}$ & $\begin{array}{c}-0.3017^{* * * *} \\
(0.0717)\end{array}$ & $\begin{array}{c}-1.2697^{* * * * *} \\
(0.0535)\end{array}$ & $\begin{array}{l}0.3912^{\text {****k }} \\
(0.0421)\end{array}$ & $\begin{array}{c}-0.7122 * * * \\
(0.0384)\end{array}$ \\
\hline$N$ & 2314 & 1050 & 1264 & 858 & 355 & 503 & 2777 & 921 & 1856 \\
\hline$R^{2}$ (within) & 0.7689 & 0.1499 & 0.8055 & 0.2963 & 0.2119 & 0.0938 & 0.7416 & 0.6988 & 0.8487 \\
\hline CHOW 1 & $10.3181^{* * * *}$ & & & $6.8472^{* * * *}$ & & & $2.3705^{* * * *}$ & & \\
\hline
\end{tabular}

Notes: The dependent variable is $P_{i t}^{*}$ as defined for (2). $B_{i t}$ is the book value of equity per share. $E_{i t}$ is the earnings per share. Standard errors of the coefficients are shown in parentheses. The second column reports the results for the entire sample period. The third and fourth columns report the results for the pre-IFRS period and IFRS period, respectively. $N$ denotes the number of observations. $R^{2}$ (within) denotes the coefficient of determination of the within-group estimator. CHOW denotes the $F$-statistic for the Chow test calculated according to (3), where the fixed effects are allowed to vary between the two periods. Observations for which the ratio equity on total assets is either negative or zero are discarded. To limit the influence of price volatility, observations for which the price-to-earnings ratio is below the 0.01 percentile or above the 0.99 percentile are excluded. Variation in share price due to mean differences across industries or to cross-listing are eliminated by regressing share price on binary variables representing the industry and the number of stock exchanges on which the company is listed, before estimation of (2).

****Denotes rejection of the null hypothesis at the $1 \%$ level.

**Denotes rejection of the null hypothesis at the $5 \%$ level.

*Denotes rejection of the null hypothesis at the $10 \%$ level.

are estimated for the pre-IFRS and IFRS periods, does not adequately describe the relationship between accounting measures and stock prices, and should be discarded. Surprisingly a negative coefficient on $E_{i t}$ is obtained in the restricted model, but the latter is misspecified according to the Chow test.

In the unrestricted model, in which different sets of coefficients are estimated for the two periods, explanatory power (measured by $R^{2}$ from the within-group estimation) increases from 51.0 per cent for the 
pre-IFRS period to 57.7 per cent for the IFRS period. The coefficient on $B_{i t}$ is lower for the IFRS period, while the coefficient on $E_{i t}$ is higher. These results suggest a higher (lower) value relevance for earnings (book value of equity) after the implementation of IFRS. The coefficient on $v_{i t}$ is negative for the IFRS period. Because $v_{i t}$ proxies for the residual effects of non-accounting variables, this finding is consistent with theory. The results for $R^{2}$ and the coefficients suggest that value relevance increased after the implementation of IFRS due to a higher value relevance of earnings.

Among the individual estimations for each country, the Chow test is significant at the 1 per cent level for Germany. The explanatory power decreases from 95.2 per cent for the pre-IFRS period to 51.6 per cent for the IFRS period. In common with the pooled estimation, the coefficient on $E_{i t}$ increases after the switch, while the coefficient on $B_{i t}$ decreases, suggesting a higher (lower) value relevance of earnings (book value of equity) after the implementation of IFRS. The coefficient on $v_{i t}$ for the pre-IFRS period is insignificant; however, this is unimportant because our primary concern is the explanatory power of the accounting measures.

For Spain, the Chow test is significant at the 1 per cent level. The explanatory power decreases from 40.5 per cent for the pre-IFRS period to 7.3 per cent for the IFRS period. The coefficient on $E_{i t}$ is negative for the pre-IFRS period. A negative relationship between price and earnings is counterintuitive, except in the case of firms that report losses (see Section 2). For the pre-IFRS period, earnings are negative for 8 per cent of the observations, and the largest reported loss is $€-4,451,000$. The corresponding figures for the IFRS period are 5 per cent and $-215,000 €$. Therefore a negative relationship between $E_{i t}$ and $P_{i t}^{*}$ for the pre-IFRS period might be explained by large losses. The coefficient on $B_{i t}$ decreases after the switch to IFRS. The coefficients on $B_{i t}$ and $E_{i t}$ are both positive but insignificant at the 5 per cent level for the IFRS period. If the significance of the coefficients is interpreted as an indicator of value relevance, irrespective of their magnitudes (Hellström, 2006), earnings became less value relevant after the introduction of IFRS. The coefficient on $v_{i t}$ for the IFRS period is insignificant.

For France, the Chow test is significant at the 1 per cent level. The explanatory power increases from 15.0 per cent for the pre-IFRS period to 80.6 per cent for the IFRS period. In common with the estimations for the pooled sample and for Germany, the coefficient on $E_{i t}$ increases after the switch, while the coefficient on $B_{i t}$ decreases, suggesting a higher 
(lower) value relevance of earnings (book value of equity) after the implementation of IFRS. The coefficient on $v_{i t}$ for the IFRS period is insignificant.

For Italy, the Chow test is significant at the 1 per cent level. The explanatory power decreases from 21.2 per cent for the pre-IFRS period to 9.3 per cent for the IFRS period. ${ }^{11}$ Unlike the estimations for Germany and France, the coefficient on $E_{i t}$ decreases after the switch, as well as the coefficient on $B_{i t}$, suggesting a lower value relevance of both earnings and book value of equity after the implementation of IFRS. The coefficient on $v_{i t}$ for the IFRS period is negative and significant in either period.

For the United Kingdom, the Chow test is significant at the 1 per cent level. The explanatory power increases from 69.9 per cent for the preIFRS period to 84.9 per cent for the IFRS period, and the coefficients on $E_{i t}$ and $B_{i t}$ are larger for the IFRS period than for the pre-IFRS period. The coefficient on $E_{i t}$ is negative for the pre-IFRS period.

To summarise, the impact of IFRS on the explanatory power of a regression of price on book value of equity per share and earnings per share varies between countries. The introduction of IFRS appears to have created a structural break in the relationship between market data and accounting measures for all countries. For Germany, Spain, and Italy, explanatory power decreases after the switch to IFRS, suggesting a decrease in value relevance. For France and the United Kingdom, explanatory power increases, suggesting the opposite. The coefficient estimates suggest that the value relevance of earnings increased in Germany, France, and the United Kingdom while it decreased in Spain and Italy, and the value relevance of book value of equity decreased in all cases except for the United Kingdom. The decrease in the coefficient on book value of equity in countries belonging to the Continental model might be due to the adoption of fair value accounting. If the book value of equity approximates market capitalisation more closely, the book-tomarket ratio, estimated by the coefficient on book value, is reduced. ${ }^{12}$

\subsection{Results for the RRM}

Table 6 reports the estimation results for equation (9) (within-group estimation of the RRM), from a pooled estimation for all five countries, and from individual estimations for each country separately.

For the pooled sample, the Chow test is insignificant. This suggests there was no structural break in the relationship between market data and the accounting measures as a result of the switch to IFRS. However, 
Table 6. Return regression model: within-group estimation results

\begin{tabular}{|c|c|c|c|c|c|c|c|c|c|}
\hline \multirow[b]{2}{*}{ Variables } & \multicolumn{3}{|c|}{ All countries } & \multicolumn{3}{|c|}{ Germany } & \multicolumn{3}{|c|}{ Spain } \\
\hline & Pooled & $G A A P$ & IFRS & Pooled & $G A A P$ & $I F R S$ & Pooled & $G A A P$ & $I F R S$ \\
\hline$B_{i t}$ & $\begin{array}{c}-1.1436 \\
(0.0304)\end{array}$ & $\begin{array}{c}-0.8631^{* * * * *} \\
(0.1982)\end{array}$ & $\begin{array}{l}3.6643^{* * * * *} \\
(0.4872)\end{array}$ & $\begin{array}{c}-1.0782^{* * * *} \\
(0.0343)\end{array}$ & $\begin{array}{c}0.1973 \\
(0.3454)\end{array}$ & $\begin{array}{c}-4.5732 * * * \\
(0.5367)\end{array}$ & $\begin{array}{l}0.5371^{\text {*** }} \\
(0.2656)\end{array}$ & $\begin{array}{c}0.2006 \\
(0.3628)\end{array}$ & $\begin{array}{c}-7.8964^{\text {***** }} \\
(1.0083)\end{array}$ \\
\hline$E_{i t}$ & $\begin{array}{l}1.6928^{* * *} \\
(0.0330)\end{array}$ & $\begin{array}{l}1.4232^{* * * *} \\
(0.1128)\end{array}$ & $\begin{array}{c}0.4886^{* * * *} \\
(0.1374)\end{array}$ & $\begin{array}{l}1.2467 * * * \\
(0.0873)\end{array}$ & $\begin{array}{l}2.9461^{* * * * *} \\
(0.2324)\end{array}$ & $\begin{array}{l}1.0735^{* * *} \\
(0.2246)\end{array}$ & $\begin{array}{r}-0.1322 \\
(0.1293)\end{array}$ & $\begin{array}{c}-0.163 \\
(0.1142)\end{array}$ & $\begin{array}{r}-0.5742 \\
(1.2541)\end{array}$ \\
\hline$N$ & 4923 & 2192 & 2731 & 949 & 272 & 677 & 365 & 223 & 142 \\
\hline$R^{2}$ (within) & 0.4971 & 0.2138 & 0.5854 & 0.7806 & 0.9099 & 0.2626 & 0.0186 & 0.0223 & 0.6581 \\
\hline \multirow[t]{2}{*}{ CHOW } & \multicolumn{3}{|l|}{0.3632} & \multicolumn{3}{|l|}{1.0464} & \multicolumn{3}{|l|}{$4.2187^{\text {***** }}$} \\
\hline & \multicolumn{3}{|c|}{ France } & \multicolumn{3}{|c|}{ Italy } & \multicolumn{3}{|c|}{ United Kingdom } \\
\hline Variables & Pooled & $G A A P$ & IFRS & Pooled & $G A A P$ & IFRS & Pooled & $G A A P$ & IFRS \\
\hline$B_{i t}$ & 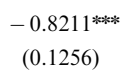 & $\begin{array}{c}0.3488 \\
(0.4233)\end{array}$ & $\begin{array}{c}-2.4314 \\
(1.5915)\end{array}$ & $\begin{array}{c}-0.7566^{\text {***** }} \\
(0.2119)\end{array}$ & $\begin{array}{l}2.9992^{* * * * * *} \\
(0.7170)\end{array}$ & $\begin{array}{c}-6.7960^{* * * *} \\
(1.5109)\end{array}$ & $\begin{array}{l}8.3391 \text { **** } \\
(0.3111)\end{array}$ & $\begin{array}{c}-1.6657^{* * *} \\
(0.7977)\end{array}$ & $\begin{aligned} * & 12.9799^{* * * * *} \\
& (0.4050)\end{aligned}$ \\
\hline$E_{i t}$ & 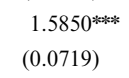 & $\begin{array}{l}0.9526^{* * * *} \\
(0.2245)\end{array}$ & $\begin{array}{l}2.1369^{* * * *} \\
(0.4296)\end{array}$ & $\begin{array}{l}1.3569^{* * * * *} \\
(0.2675)\end{array}$ & $\begin{array}{c}-1.0853^{* *} \\
(0.4471)\end{array}$ & $\begin{array}{l}4.3172^{* * * *} \\
(0.8175)\end{array}$ & $\begin{array}{l}1.1615^{*} \\
(0.6394)\end{array}$ & $\begin{array}{r}-0.1148 \\
(0.4339)\end{array}$ & $\begin{array}{c}-6.8769^{\text {**** }} \\
(0.8298)\end{array}$ \\
\hline$N$ & 1358 & 720 & 638 & 497 & 252 & 245 & 1754 & 725 & 1029 \\
\hline$R^{2}$ (within) & 0.5148 & 0.0703 & 0.6745 & 0.0865 & 0.1489 & 0.3079 & 0.8052 & 0.2771 & 0.9223 \\
\hline CHOW & 0.4643 & & & $2.7950^{* * * * *}$ & & & $1.8749 * * * *$ & & \\
\hline
\end{tabular}

Notes: The dependent variable is $R_{i t}^{*}$ as defined in (8). $E_{i t}$ is the EBITDA per share. $\Delta E_{i t}$ is the annual change in EBITDA per share. Standard errors of the coefficients are shown in parentheses. The second column reports the results for the entire sample period. The third and fourth columns report the results for the pre-IFRS period and IFRS period, respectively. $N$ denotes the number of observations. $R^{2}$ (within) denotes the coefficient of determination of the within-group estimator. CHOW denotes the $F$-statistic for the Chow test calculated according to (3), where fixed effects are allowed to vary between the two periods. Observations for which the ratio equity on total assets is either negative or zero are discarded. To reduce the problem of transitory earnings, observations for which the earnings per share are negative have been excluded. To limit the influence of price volatility, observations for which the price-toearnings ratio is below the 0.01 percentile or above the 0.99 percentile are excluded. Variation in share price due to mean differences across industries or to cross listing is eliminated by regressing share price on binary variables representing the industry and the number of stock exchanges on which a company is listed, before estimation of (8). **** Denotes rejection of the null hypothesis at the $1 \%$ level.

**Denotes rejection of the null hypothesis at the $5 \%$ level.

*Denotes rejection of the null hypothesis at the $10 \%$ level.

explanatory power measured by $R^{2}$ increases from 21.4 per cent for the pre-IFRS period to 58.5 per cent for the IFRS period. The coefficient on $E_{i t}$ (which in this case represents EBITDA per share, not earnings per share) is negative for the pre-IFRS period and positive for the IFRS period. In the restricted model based on (8), in which the same coefficients are estimated for the pre-IFRS and IFRS periods, the coefficient on $E_{i t}$ is negative. The coefficients on $\Delta E_{i t}$ are positive in all three regressions (the restricted regression and the two unrestricted regressions in which different sets of coefficients are estimated for the two periods). For the IFRS period, the coefficient on $E_{i t}$ is larger in 
absolute value for the IFRS period than it is for the pre-IFRS period. In contrast, the coefficient on $\Delta E_{i t}$ for the IFRS period is smaller than the coefficient for the pre-IFRS period.

Among the individual estimations for each country, for Germany the Chow test is insignificant. As before, it appears the IFRS did not cause a significant change in the relationship between market data and accounting measures. The explanatory power decreases from 91.0 per cent for the pre-IFRS period to 26.3 per cent for the IFRS period. The coefficient on $E_{i t}$ is negative in the pooled model and in the model for the IFRS period. As in the estimation over the entire sample, the coefficient on $\Delta E_{i t}$ for the IFRS period is smaller than the coefficient for the pre-IFRS period.

For Spain, the Chow test is significant at the 1 per cent level. This suggests the IFRS caused a significant change in the relationship between market data and accounting measures. The explanatory power increases from 2.2 per cent for the pre-IFRS period to 65.8 per cent for the IFRS period. However, for the IFRS period, individual effects for 110 companies are estimated using only 142 observations. The increase in explanatory power may be due to insufficient degrees of freedom in the estimation for the IFRS period. The coefficient on $\Delta E_{i t}$ is insignificant in the pooled model and insignificant in the estimations for both the preIFRS and the IFRS period. The coefficient on $E_{i t}$ is positive and significant in the pooled model. This coefficient is insignificant for the pre-IFRS period and negative and significant for the IFRS period.

For France, the Chow test is insignificant, suggesting the IFRS did not have a significant impact on the relationship between market data and accounting measures. The explanatory power increases from 7.0 per cent for the pre-IFRS period to 67.5 per cent for the IFRS period. This increase does not appear to be due to insufficient degrees of freedom: for the IFRS period, 447 individual effects are estimated using 638 observations. The coefficient on $E_{i t}$ is negative and significant in the pooled model and this coefficient is insignificant for both periods in the unrestricted model. The coefficient on $\Delta E_{i t}$ is positive and significant in the pooled model and for both periods in the unrestricted model. This coefficient increases after the switch to IFRS.

For Italy, the Chow test is significant at the 1 per cent level. This suggests the IFRS caused a significant change in the relationship between market data and accounting measures. The explanatory power increases from 14.9 per cent for the pre-IFRS period to 30.8 per cent for the IFRS period. However, for the IFRS period, individual effects for 110 companies are estimated using only 142 observations. As in the 
estimation for Spain, the increase in explanatory power for the IFRS period may be due to insufficient degrees of freedom. The coefficient on $E_{i t}$ in the pooled model is negative and significant, while the coefficient on $\Delta E_{i t}$ is positive and significant. As in the pooled model, the coefficient on $E_{i t}$ for the IFRS period is negative and significant, while the coefficient on $\Delta E_{i t}$ is positive and significant. For the pre-IFRS period, the coefficient on $E_{i t}$ is positive and significant and the coefficient on $\Delta E_{i t}$ is negative and significant.

For the United Kingdom, the Chow test is significant at the 1 per cent level. This suggests the IFRS caused a significant change in the relationship between market data and accounting measures. The explanatory power increases from 27.71 per cent for the pre-IFRS period to 92.23 per cent for the IFRS period. The coefficient on $E_{i t}$ is positive and significant for the pooled model. For the unrestricted model, the coefficient on $E_{i t}$ is positive and significant for the IFRS period, but negative and significant for the pre-IFRS period. The coefficient on $\Delta E_{i t}$ is positive and significant at the 10 per cent level for the pooled model. For the unrestricted model the coefficient on $\Delta E_{i t}$ is negative, and it is significant at the 1 per cent level for the IFRS period, but not significant for the pre-IFRS period.

To summarise, estimations of the RRM suggest that the introduction of IFRS produced a structural break in the relationship between market data and accounting measures for Spain, Italy, and the United Kingdom, but not for France and Germany, for which changes in value relevance measured by the explanatory power of the RRM before and after the implementation of IFRS might have occurred for other reasons. No structural break is found for the pooled sample, but the explanatory power of the RRM is larger for the IFRS period than it is for the preIFRS period. On the criterion of explanatory power, the PRM and RRM estimations are consistent in suggesting that for Germany, value relevance was lower in the pre-IFRS period than it was in the IFRS period. The RRM suggests that for Spain, Italy, and the United Kingdom, value relevance was higher in the IFRS period than it was in the pre-IFRS period. The results for Spain and Italy are not consistent with the PRM, for which value relevance is found to have decreased in the IFRS period.

There are several possible causes of inconsistency between the PRM and RRM results. The RRM does not account for the effect of book value of equity per share on stock returns, but it does account for earnings per share. Observations for which earnings are negative are excluded from the RRM estimation, and EBITDA per share replaces earnings per share. Consequently, and in contrast to the PRM, the RRM 
should not be affected by transitory earnings. The estimation of the RRM excludes observations for 2005, and equation (8) fails to account for non-accounting variables. In principle, adjustments could be made to the specification of the RRM for greater consistency with the PRM; in practice, however, the required adjustments are impractical. Including the 2005 observations would introduce noise into the estimations, and including non-accounting variables would cause a large reduction in the number of observations. Finally, the issue of accounting recognition lag cannot be addressed, because of the short duration of the sample period.

\section{Other Measures of Accounting Quality}

Other measures of accounting quality that may be used to assess the effects of IFRS are earnings smoothing and timely loss recognition (Barth et al., 2008). The former can be proxied by earnings variability: the lower is the variance of earnings, the greater is the likelihood that earnings-smoothing practices are used (Lang et al., 2006). The frequency of large losses provides an indication as to whether earnings-smoothing practices are used: large losses should be more frequent when there is no smoothing.

Earnings quality is of paramount importance for investors because earnings are often used in performance-based compensation packages and debt contracts. Overstated earnings may result in higher emoluments for managers and higher risk for lenders (due to stronger informational asymmetries). Allocative efficiency may also be impaired (Schipper and Vincent, 2003).

By limiting management discretion, IFRS should discourage earningssmoothing practices, because IFRS prohibit the creation of hidden reserves that can be used to conceal large losses (Barth et al., 2008). An improvement in earnings quality after the switch is expected to be weaker in the United Kingdom, due to a better protection for outsiders than in Continental Europe (Leuz et al., 2003).

\subsection{Earnings Smoothing and IFRS}

The chosen metric for earnings smoothing is the variability of annual change in net income scaled by total assets (Lang et al., 2006), denoted by $\Delta I_{i t}$. In order to allow for variables other than management discretion that might affect earnings variability, a regression model identifies determinants of variability in earnings other than earnings smoothing. The standard deviations of the disturbances from this regression for the 
pre-IFRS period and the IFRS period, $\Delta I_{i t}^{*}$, are used to test whether there was any change in the propensity for companies to smooth earnings. Following Barth et al. (2008), the specification of the regression model is

$$
\begin{aligned}
\Delta I_{i t}= & \beta_{0}+\beta_{1} S I Z E_{i t}+\beta_{2} G R O W_{i t}+\beta_{3} E I S S U E+\beta_{4} L E V_{i t} \\
& +\beta_{5} D_{I S S U E_{i t}}+\beta_{6} T U R N_{i t}+\beta_{7} C F_{i t}+\beta_{8} A U D_{i} \\
& +\beta_{9} N U M E X_{i}+\beta_{10} C L O S E_{i t}+\beta_{11} X_{L} I S T_{i}+\beta_{12} S E C_{i}
\end{aligned}
$$

where $S I Z E_{i t}$ is natural logarithm of market value of equity; GROW $W_{i t}$ is annual change in sales; $E I S S U E_{i t}$ is annual change in common stock; $L E V_{i t}$ is total liabilities divided by book value of equity; DISSUE $E_{i t}$ is change in total liabilities; $T U R N_{i t}$ is sales divided total assets; $C F_{i t}$ is annual net cash flow from operating activities divided by total assets; $A U D_{i}$ is 1 if the firm's auditor is PwC, KPMG, Arthur Andersen, Ernst and Young, or Deloitte and Touche, and 0 otherwise; $N U M E X_{i}$ is the number of exchanges on which the company's shares are listed; CLOSE $E_{i t}$ is the percentage of closely held shares reported by WorldScope; $X L I S T_{i}$ is 1 if the company is cross listed on a U.S. stock exchange (other than the main stock exchange) and 0 otherwise; $S E C 1_{i}-S E C 10_{i}$ are industry dummies (Industry Classification Benchmark index).

We calculate clustered standard errors for the regression coefficients to allow for intra-group correlation that might otherwise render the standard errors downward biased. For consistency with the analysis of value relevance, observations for which the price-to-earnings ratio is below the 0.01 percentile or above the 0.99 percentile are excluded. We employ an $F$-test to examine whether there was any change in the standard deviation of the residuals from (9).

\subsection{Timely Loss Recognition and IFRS}

A second measure of accounting quality is timely loss recognition. The chosen metric is the frequency of large negative net income, $L N E G_{i t}$. Following Barth et al. (2008), $L N E G_{i t}$ appears as an independent variable in the following probit regression:

$$
\begin{aligned}
\operatorname{IFRS}_{i t}= & \beta_{0}+\beta_{1} \text { SIZE }_{i t}+\beta_{2} \text { GROW }_{i t}+\beta_{3} E I S S U E+\beta_{4} L E V_{i t} \\
& +\beta_{5} \text { DISSUE }_{i t}+\beta_{6} \text { TURN }_{i t}+\beta_{7} C F_{i t}+\beta_{8} A U D_{i} \\
& +\beta_{9} N U M E X_{i}+\beta_{10} C L O S E_{i t}+\beta_{11} X L I S T_{i} \\
& +\beta_{12} S E C_{i}+\beta_{12} L N E G_{i t}+\varepsilon_{i t}
\end{aligned}
$$


where $I F R S_{i t}$ is 1 for observations for the IFRS period, and 0 otherwise; $L N E G_{i t}$ is 1 if $I_{i t}<-0.20$, and 0 otherwise; $\varepsilon_{i t}$ is the residuals; and other variables are as defined above. As before, we use clustered standard errors, and we exclude observations for which the price-to-earnings ratio is below the 0.01 percentile or above the 0.99 percentile. A positive (and significant) coefficient on $L N E G_{i t}$ indicates more frequent recognition of losses in the IFRS period than in the pre-IFRS period. Accordingly, a positive coefficient on $L N E G_{i t}$ suggests accounting quality has improved following the introduction of IFRS.

\subsection{Results for Earnings Smoothing and Timely Loss Recognition}

Table 7 reports the estimation results for (9) and (10). We do not find evidence that the introduction of IFRS increased the variability of earnings in any of the five countries. Accordingly, earnings-smoothing practices do not appear to have become less prevalent following the introduction of IFRS. A similar conclusion is drawn concerning timely loss recognition. The coefficient on $L N E G_{i t}$ is negative and significant for France, Italy, and the United Kingdom. For Germany, the coefficient is negative but insignificant. For Spain, there were no observations with $L N E G_{i t}=1$ in the IFRS period, suggesting less timely loss recognition in this period.

\section{Conclusions}

This paper presents an analysis of the effects of the compulsory adoption by European-listed companies in 2005 of IFRS. We examine the extent to which accounting measures are reflected in share price and cum-dividend returns, or value relevance, before and after this event. To this end, we estimate panel-data regressions using data for 3,721 companies listed on five European stock markets, for the period 2002-2007. We employ a Chow test to identify structural breaks in the regression coefficients before and after 2005.

Our main findings are as follows. In a regression of share price on book value of equity per share and earnings per share, for all companies in the sample, IFRS are found to have increased value relevance of earnings, while value relevance of book value of equity has decreased. The explanatory power of the regression has increased. For individual countries, the effects of IFRS are mixed. For Germany, similar to what found for the whole sample, value relevance of earnings has increased 
Table 7. Results for earnings smoothing and timely loss recognition

\begin{tabular}{lccccc}
\hline & Germany & Spain & France & Italy & $\begin{array}{c}\text { United } \\
\text { Kingdom }\end{array}$ \\
\hline$S D_{1}$ & $N=188$ & $N=31$ & $N=717$ & $N=240$ & $N=1,489$ \\
& 0.1025 & 0.0398 & 0.0902 & 0.0490 & 0.2149 \\
$S D_{2}$ & $N=498$ & $N=189$ & $N=650$ & $N=274$ & $N=1,616$ \\
& 0.1064 & 0.0297 & 0.0597 & 0.0396 & 0.1601 \\
$S D_{1} / S D_{2}$ & 0.9631 & $1.3399^{* *}$ & $1.5099^{* * * *}$ & $1.2385^{* * * *}$ & $1.3428^{* * * *}$ \\
Less earnings & No & No & No & No & No \\
smoothing? & $N=880$ & $N=278$ & $N=1,650$ & $N=634$ & $N=2,946$ \\
$L N E G_{i t}$ & -0.0072 & (a) & $-1.2324^{* * * *}$ & $-1.3054^{* * *}$ & $-0.6394^{* * * *}$ \\
& No & No & No & No & No \\
More timely loss & & & & & \\
recognition? & & & & & \\
\hline
\end{tabular}

Notes: $S D_{1}$ is the standard deviation of $\Delta I_{i t}^{*}$ for the pre-IFRS period, while $S D_{2}$ is the standard deviation of $\Delta I_{i t}^{*}$ for the IFRS period. $S D_{1} / S D_{2}$ is the ratio of the standard deviation of $\Delta I_{i t}^{*}$ for the pre-IFRS period to the standard deviation of $\Delta I_{i t}^{*}$ for the IFRS period. $N$ is the number of observations. $L N E G_{i t}$ is the coefficient on the variable $L N E G_{i t}$ defined in equation (10).

(a) Indicates that for Spain all cases for which $L N E G_{i t}=1$ occur during the pre-IFRS period. Therefore, these results are not supportive of more timely loss recognition.

****Denotes rejection of the null hypothesis at the $1 \%$ level.

**Denotes rejection of the null hypothesis at the $5 \%$ level.

*Denotes rejection of the null hypothesis at the $10 \%$ level.

after the introduction of IFRS, while that of book value of equity has decreased. However, the explanatory power of the regression has decreased. For Spain, the explanatory power has decreased and value relevance of both earnings and book value of equity has decreased. For France, consistent to what found for the whole sample, the explanatory power has increased, and value relevance of earnings has also increased, while that of book value of equity has decreased. For Italy, the explanatory power has decreased and the value relevance of both earnings and book value of equity has also decreased. For the United Kingdom, the explanatory power has increased and the value relevance of both earnings and book value of equity has increased.

In regressions of cum-dividend return on EBITDA per share and changes in EBITDA per share, there are structural breaks following the introduction of IFRS for Spain, Italy, and the United Kingdom, for which the explanatory power of the regression increased. For Spain, these results might be driven by relatively low numbers of observations for these regressions. Tests for earnings smoothing and timely loss recognition, commonly used in the literature to assess accounting quality alongside tests for value relevance, do not suggest an improvement in accounting quality following the introduction of IFRS. 
Overall, our results suggest that the main aim of IFRS, to improve cross-border comparability of financial statements by means of harmonisation of accounting standards, may not have been achieved. Significant differences between European accounting standards still remain and the impact of the introduction of IFRS has been varied. The consistency of implementation and enforcement of IFRS in different European countries, and the impact of national factors associated with culture and legal system, merits further investigation in future research.

\section{Notes}

1. The SEC states "The Commission in 2011 would determine whether to proceed with rulemaking to require that US issuers use IFRS beginning in 2014 if it is in the public interest and for the protection of investors to do so." Roadmap for the Potential Use of Financial Statements Prepared in Accordance with International Financial Reporting Standards by US Issuers (p. 10).

2. Several studies have multiple objectives, including the investigation of value relevance. For simplicity, Table 2 reports the findings on value relevance only.

3. Residual earnings are current earnings minus expected earnings, where expected earnings are the product of the previous book value of equity and the cost of capital.

4. Barth et al. (2008) pre-regress $P_{i t}$ on industry and country effects. We examine country effects by estimating (2) for each country and for the entire sample. Industry effects are identified using the Industry Classification Benchmark index. Cross-listing effects are identified using the number of stock exchanges on which the company is listed.

5. Hellström (2006) mitigates scale effects by deflating all variables by the book value of equity from the previous year, and by using logarithmic transformations of all variables.

6. Other studies that use market value (rather than share price) as dependent variable employ a range of deflators, including market value at the beginning of the year, book value of equity, number of shares, and sales (Dedman et al., 2009). Consensus on the best deflator has not been achieved (Akbar and Stark, 2003).

7. In an OLS regression of $P_{i t}$ on $B_{i t}$ and $E_{i t}$ (the PRM), the practice of dividing all variables by $P_{i t-1}=B_{i t-1}+E_{i t-1}+u_{i t-1}$, where $u_{i t-1}=\eta_{i}+\varepsilon_{i t-1}$, produces $\frac{P_{i t}}{P_{i t-1}}=$ $\frac{B_{i t}}{P_{i t-1}}+\frac{E_{i t}}{P_{i t-1}}+\frac{u_{i t}}{P_{i t-1}}$. Deflation of the error term $u_{i t}$ by $P_{i t-1}$ transforms $u_{i t}$ as follows: $\frac{u_{i t}}{P_{i t-1}}=\frac{\eta_{i t}+\varepsilon_{i t}}{B_{i t-1}+E_{i t-1}+\eta_{i}+\varepsilon_{i t-1}}$. Although both the numerator and denominator contain the individual effects $\eta_{i}$, the impact of $\eta_{i}$ is greater on the numerator than on the denominator, produce an upward bias in $\frac{u_{i t}}{P_{i t-1}}$ for $\eta_{i}>0$ and a downward bias for $\eta_{i}<0$.

8. To increase the robustness of our results, we repeat the estimation of equations (2), (3), and (8) including year effects. Apart from the case of Italy when the PRM is employed (see footnote 11), the estimation results do not change.

9. Transitory earnings are expenses or revenues that are unlikely to recur frequently, such as extraordinary items. Using profitability measures that are not affected by extraordinary items (such as EBITDA) helps reduce the problem. Losses are also considered to be transitory, due to the liquidation option that exists for shareholders (Hayn, 1995). Studies based on the RRM may also suffer from accounting recognition lag: prices may reflect information more quickly than accounting measures. Accounting recognition lag can be tackled by using larger "windows" for the calculation of returns. 
However, due to the limited number of years for which data are available and a lack of quarterly data for earnings, we are unable to employ this approach.

10. Voluntary adoption of IFRS has been found to lead to better accounting quality. This might be because voluntary adopters have incentives to comply with IFRS rules. If there were no incentives, there would have been no reason to adopt IFRS voluntarily. When the adoption of IFRS becomes compulsory, there might be no incentive to comply with IFRS rules. Compulsory adoption of IFRS has not improved accounting quality (Christensen et al., 2007). We thank an anonymous referee for this remark.

11. When year effects are considered, there is a slight improvement in the explanatory power of the PRM. The explanatory power is 27.2 per cent in the pre-IFRS period and 27.3 per cent in the IFRS period.

12. For example, let $B_{H C}$ denote book value of equity under historical cost accounting, $B_{F V}$ denote book value of equity under fair value accounting, and $M V$ denote market value of equity (unaffected by accounting standard). Assume a positive difference between fair value and historical cost of assets recorded in the financial statements, $B_{H C}<B_{F V}$. In a regression of the type $M V=\beta B$, where $B$ is either $B_{H C}$ or $B_{F V}, \beta=M V / B . B_{H C}<B_{F V}$ implies $M V / B_{H C}>M V / B_{F V}$. Therefore a change in $B_{H C}$ produces a larger $\beta$ when $B_{F V}$ is used than it does when $B_{H C}$ is used.

\section{References}

Akbar, S. and A.W. Stark, "Discussion of Scale and the Scale Effect in Market-Based Accounting Research," Journal of Business Finance and Accounting 30(1) (2003), pp. 57-72.

Ali, A. and L.S. Hwang, "Country-Specific Factors Related to Financial Reporting and the Value Relevance of Accounting Data," Journal of Accounting Research 38(1) (2000), pp. 1-21.

d'Arcy, A., "Accounting Classification and the International Harmonisation Debate-An Empirical Investigation,” Accounting, Organizations and Society 26 (2001), pp. 327-349.

Babalyan, L., "Association between Accounting Earnings and Stock Returns as a Measure of Value Relevance of Accounting Standards: Empirical Evidence from the Swiss Market," 2001. Available at http://www.ssrn.com/abstract $=301923$

Barth, M.E., W.H. Beaver, J.R.M. Hand and W.R. Landsman, "Accruals, AccountingBased Valuation Models, and the Prediction of Equity Values," Journal of Accounting Auditing and Finance 20(4) (2005), pp. 311-345.

Barth, M.E., W.R. Landsman and M.H. Lang, "International Accounting Standards and Accounting Quality," Journal of Accounting Research 46(3) (2008), pp. 467-498.

Bartov, E., S. Goldberg and M. Kim, "Comparative Value Relevance among German, U.S. and International Accounting Standards: A German Stock Market Perspective," Journal of Accounting, Auditing and Finance 20 (2005), pp. 95-119.

Beneish, M.D., B.P. Miller and T.L. Yohn, "The Effect of IFRS Adoption on CrossBorder Investment in Equity and Debt Markets," 2009. Available at http://papers.ssrn. com/sol3/papers.cfm?abstract_id $=1403451$

Brown, S., K. Lo and T. Lys, "Use of $R^{2}$ in Accounting Research: Measuring Changes in Value Relevance Over the Last Four Decades," Journal of Accounting and Economics 28 (1999), pp. 83-115.

Cairns, D., "The Use of Fair Value in IFRS," Accounting in Europe 3(1) (2006), pp. 5-22.

Callao, S., J. Jarne and J. Laínez, "Adoption of IFRS in Spain: Effect on the Comparability and Relevance of Financial Reporting," Journal of Accounting, Auditing and Taxation 16 (2007), pp. 148-178.

(C) 2010 Blackwell Publishing Ltd. 
Collins, D.W., M. Pincus and H. Xie, "Equity Valuation and Negative Earnings: The Role of Book Value of Equity," The Accounting Review 75 (1999), pp. 29-61.

Christensen, H.B., E. Lee and M. Walker, "Incentives or Standards: What Determines Accounting Quality Changes Around IFRS Adoption?" Working Paper, Manchester Business School, 2007. Available at http://papers.ssrn.com/sol3/papers.cfm?abstract_ id $=1013054$

Daske, H., L. Hail, C. Leuz and R. Verdi, "Mandatory IFRS Reporting Around the World: Early Evidence on the Economic Consequences," Journal of Accounting Research 46 (2008), pp. 1085-1142.

Delvaille, P., G. Ebbers and C. Saccon, "International Financial Reporting Convergence: Evidence from Three Continental European Countries," Accounting in Europe 2(1) (2005), pp. 137-164.

Demaria, S. and D. Dufour, "First Time Adoption of IFRS, Fair Value Option, Conservatism: Evidences from French listed companies," Paper published presented at 30 éme colloque de l'EAA, Lisbon, 2007.

Dedman, E., S. Mouselli, Y. Shen and A.W. Stark, "Accounting, Intangible Assets, Stock Market Activity, and Measurement and Disclosure Policy-Views from the UK," Abacus 45(3) (2009), pp. 312-341.

Devalle, A., "The impact of the gains and losses recognised directly in equity on the company profitability-An empirical evidence from European Stock Exchanges," Economia Aziendale 2000 web, 5/2008, pp. 25-49. Available at http://www.ea2000.it

Dobija, D. and K. Klimczak, "Value Relevance and the Development of Accounting Regulation and Market Institutions in a Transition Economy: Case of Poland," 2007. Available at http://www.ssrn.com/abstract $=1084423$

Easton, P. and G. Sommers, "Scale and the Scale Effect in Market-Based Accounting Research," Journal of Business Finance \& Accounting 30(1) (2003), pp. 25-55.

Ely, K. and G. Waymire, "Accounting Standard-Setting Organizations and Earnings Relevance: Longitudinal Evidence from NYSE Common Stocks, 1927-93," Journal of Accounting Research 37 (1999), pp. 293-317.

Flower, J. and G. Ebbers, Global Financial Reporting (New York: Palgrave Macmillan, 2002), p. 56.

Francis, J. and K. Schipper, "Have Financial Statements Lost their Relevance?," Journal of Accounting Research 37 (1999), pp. 319-352.

Gjerde, Ø., K. Knivsfla and F. Sættem, "The Value Relevance of Financial Reporting in Norway 1965-2004," 2008. Available at http://www.ssrn.com/abstract $=962051$

Gornik-Tomaszewski, S. and E.K. Jermakowicz, "Accounting-Based Valuation of Polish Listed Companies," Journal of International Financial Management and Accounting 12(1) (2001), pp. 50-74.

Gu, Z., "Scale Factor and R2: Further Analysis," Working Paper, Carnegie Mellon University, 2001.

Harris, M. and K. Muller, "The Market Valuation of IAS Versus US-GAAP Accounting Measures Using Form 20-F Reconciliations," Journal of Accounting and Economics 26 (1999), pp. 285-312.

Harris, T., M. Lang and H. Möller, "The Value Relevance of German Accounting Measures: An Empirical Analysis," Journal of Accounting Research 32 (1994), pp. 187-209.

Hayn, C., "The Information Content of Losses," Journal of Accounting and Economics 20 (1995), pp. 125-153.

Hellström, K., "The Value Relevance of Financial Accounting Information in a Transition Economy: The Case of Czech Republic," European Accounting Review 15(3) (2006), pp. 325-349. 
Holthausen, R.W. and R.L. Watts, "The Relevance of the Value-Relevance Literature for Financial Accounting Standard Setting," Journal of Accounting and Economics 31 (2001), pp. 3-75.

Horton, J. and G. Serafeim, "Market Reaction to and Valuation of IFRS Reconciliation Adjustments: First Evidence from the United Kingdom," 2008. Available at http:// www.ssrn.com/abstract $=923582$

Hung, M. and K. Subramanyam, "Financial Statement Effects of Adopting International Accounting Standards: The Case of Germany," Review of Accounting Studies 12 (2007), pp. 623-657.

Jaafar, A. and S. McLeay, "Country Effects and Sector Effects on the Harmonization of Accounting Policy Choice," Abacus 43 (2007), pp. 156-189.

Jermakowicz, E., J. Prather-Kinsey and I. Wulf, "The Value Relevance of Accounting Income Reported by DAX-30 German Companies," Journal of International Financial Management and Accounting 18 (2007), pp. 151-191.

Joos, P. and M. Lang, "The Effects of Accounting Diversity: Evidence from the European Union," Journal of Accounting Research 32 (1994), pp. 141-168.

Kimberly, F., "The Effect of Growth on the Value Relevance of Accounting Data," Journal of Business Research 55 (2002), pp. 69-78.

King, R. and J. Langli, "Accounting Diversity and Firm Valuation," The Journal of International Accounting 33(5) (1998), pp. 529-567.

La Porta, R., F. Lopez-De-Silanes, A. Shleifer and W. Vishny, "Legal Determinants of External Finance," The Journal of Finance 52 (1997), pp. 1131-1150.

Lang, M., J. Raedy and W. Wilson, "Earnings Management and Cross Listing: Are Reconciled Earnings Comparable to U.S. Earnings?," Journal of Accounting and Economics 42 (2006), pp. 255-283.

Lev, B. and P. Zarowin, "The Boundaries of Financial Reporting and How to Extend Them," Journal of Accounting Research 37 (1999), pp. 353-385.

Leuz, C., D. Nanda and P.D. Wysocky, "Earnings Management and Investor Protection: An International Comparison," Journal of Financial Economics 69 (2003), pp. 505-527.

Lin, Z. and F. Chen, "Value Relevance of International Accounting Standards Harmonization: Evidence from A- and B-Share Markets in China," Journal of International Accounting, Auditing and Taxation 14 (2005), pp. 79-103.

Naceur, B. and W. Nachi, "Does the Tunisian Accounting Reform Improve the Value Relevance of Financial Information?," 2007. Available at http://www.ssrn.com/ abstract $=888922$

Niskanen, J., J. Kinnunen and E. Kasanen, "The Value Relevance of IAS Reconciliation Components: Empirical Evidence from Finland," Journal of Accounting and Public Policy 19 (2000), pp. 119-137.

Nobes, C., "Towards a General Model of the Reason for International Differences in Financial Reporting," Abacus 34 (1998), pp. 162-187.

Nobes, C., "The Survival of International Differences under IFRS: Towards a Research Agenda," Accounting and Business Research 36(3) (2006), pp. 233-245.

Nobes, C. and R. Parker, Comparative International Accounting, 10th ed. (Harlow: Prentice Hall, 2008).

OECD Observer, "A Transparent Roadmap to Recovery-Governments must put Transparency and Accountability at the Heart of all Rescue and Reform Measures if They are to Regain Public Trust and Investor Confidence," Here is why, No 273, June, 2009 .

Ohlson, J., "Earnings, Book Values and Dividends in Equity Valuation," Contemporary Accounting Research 11 (1995), pp. 661-687.

(C) 2010 Blackwell Publishing Ltd. 
Papadaki, A. and G. Siougle, "Value Relevance of Price, Earnings and Book Values in the Athens Stock Exchange," Managerial Finance 33(5) (2007), pp. 309-320.

Pilbeam, K., Finance and Financial Markets, 2nd ed. (New York: Palgrave Macmillan, 2005).

Schiebel, A., "Value Relevance of German GAAP and IFRS Consolidated Financial Reporting: An Empirical Analysis of the Frankfurt Stock Exchange," 2006. Available at http://ssrn.com/abstract $=916103$

Schipper, K. and L. Vincent, "Earnings Quality," Accounting Horizons, 17 (Suppl.) (2003), pp. 97-110.

Securities and Exchange Commission, "Roadmap for the Potential Use of Financial Statements Prepared in Accordance with International Financial Reporting Standards by U.S. Issuers," 2008. Available at http://www.sec.gov/spotlight/ifrsroadmap.htm

Van der Meulen, S., A. Gaeremynck and M. Willekens, "Attribute Differences between U.S. GAAP and IFRS Earnings: An Explanatory Study," The International Journal of Accounting 42 (2007), pp. 123-142. 